\title{
In vitro microleakage of six different dental materials as intraorifice barriers in endodontically treated teeth
}

\author{
Ki Sun LEE ${ }^{1 \dagger}$, Jong Sook KIM²†, Dong Yul LEE³, Ryan Jin Young KIM and Joo Hee SHIN²,5 \\ ${ }^{1}$ Dental Center, Korea University Guro Hospital, 148 Gurodong-ro, Guro-gu, Seoul 152-703, South Korea \\ ${ }^{2}$ Department of Orthodontics, Graduate School of Clinical Dentistry, Korea University, 145 Anam-ro, Seongbuk-gu, Seoul, 136-701, South Korea \\ ${ }^{3}$ Department of Orthodontics, Korea University Guro Hospital, 148 Gurodong-ro, Guro-gu, Seoul 152-703, South Korea \\ ${ }^{4}$ Department of Conservative Dentistry, School of Dentistry, Seoul National University, 101 Daehakno, Jongno-gu, Seoul 110-749, South Korea \\ ${ }^{5}$ Department of Conservative Dentistry, Korea University Guro Hospital, 148 Gurodong-ro, Guro-gu, Seoul 152-703, South Korea \\ Corresponding author, Joo-Hee SHIN; E-mail: endoshin11@gmail.com
}

\begin{abstract}
The aim of this study was to compare the coronal sealing ability of six different dental materials: Three MTA-based cements and three established restorative materials by in vitro dye penetration method. For in vitro infiltration experiments, seventy extracted single-rooted human teeth were used. After crowns of teeth were reduced, root canals were prepared, and filled with gutta-percha cone. Teeth were randomly divided into 6 groups with 10 teeth per group. The orifice of each tooth was prepared to $3 \mathrm{~mm}$ depth and filled with the following materials: (I) ProRoot WMTA; (II) EndoCem Zr; (III) Angelus White; (IV) LuxaCore; (V) Fuji II LC; and (VI) Elite. After 5,000 cycles of thermocycling between $5^{\circ} \mathrm{C}$ and $55^{\circ} \mathrm{C}$, dye penetration of each specimen was measured. The order of less dye infiltration of coronal filling materials was: ProRoot WMTA $<$ LuxaCore, Angelus White $<$ EndoCem $\mathrm{Zr}<$ Fuji II LC $<$ Elite $(p<0.05)$.
\end{abstract}

Keywords: Coronal sealing ability, Dye penetration, Mineral trioxide aggregate

\section{INTRODUCTION}

Coronal leakage after the completion of root canal treatment has been recognized as one of the most important endodontic failure reason ${ }^{1}$. Lacks of the coronal seal such as delay in placement of a permanent restoration, fracture of the coronal restoration, and inadequate thickness of the temporary restoration may result in the possibility of coronal recontamination of obturated root canals ${ }^{1)}$. Different restorative materials have been studied for producing a successful coronal barrier and different results were obtained ${ }^{2-8}$. Although various materials have been described as coronal sealing materials, mineral trioxide aggregate (MTA) derived materials have not been sufficiently studied despite their superior sealing ability and biocompatibility.

Since MTA was introduced by Torabinejad at Loma Linda University, California, USA, it has been widely studied as a material of choice for root-end filling ${ }^{9-12}$, direct pulp capping ${ }^{13-15)}$, perforation repair in roots or furcations ${ }^{16,17)}$, and apexification ${ }^{18,19)}$. In addition, it is useful for the troublesome strip perforations and perforating resorptive defects ${ }^{20)}$. MTA consists of tricalcium silicate, tricalcium aluminate, tricalcium oxide and other mineral oxides such as bismuth oxide ${ }^{21}$. When MTA powder is mixed with water, calcium hydroxide and calcium silicate hydrate are initially transformed into a poorly crystallized and porous solid gel $^{22)}$. Sarkar et al. ${ }^{23)}$ reported that MTA leached a structure composed of calcium, phosphorus, and oxygen, similar to hydroxyapatite (HA). In addition, it was

\footnotetext{
${ }^{\dagger}$ Ki Sun LEE and Jong Sook KIM contributed equally to this work. Color figures can be viewed in the online issue, which is available at J-STAGE.

Received Sep 2, 2014: Accepted Jan 30, 2015

doi:10.4012/dmj.2014-242 JOI JST.JSTAGE/dmj/2014-242
}

revealed that this phenomenon increases the sealing ability of MTA and promotes the regeneration and remineralization of hard tissues. Based on these results, the authors suggested that MTA bonds chemically to dentin when it is placed adjacent to dentin, possibly via a diffusion controlled reaction. Many studies ${ }^{21,22,24)}$ demonstrated the presence of phosphorus and calcium, the main components of $\mathrm{HA}$ in the hard structure, between the pulp-MTA interfaces. Recent studies ${ }^{23-25)}$ also showed that a layer of HA forms over the material that fills the voids or surface defects after MTA placement. Formation of this layer develops a chemical bond between MTA and the dentin walls. It was reported that formation of apatite crystals within the collagen fibrils support the reaction between MTA and dentin that eventually formed a chemical bond ${ }^{23}$. Based on these previous research findings, it can be thought that MTA might be effective in preventing coronal leakage after root canal treatment. However, very few studies have been performed to study the efficacy of MTA for coronal sealing. Therefore, the purpose of this study was to compare the coronal sealing ability of MTA-derived materials to several established restorative materials such as composite resin, resin-modified glass ionomer (RMGI), and zinc phosphate cement (ZPC) in extracted human teeth using dye penetration method. The null hypothesis of this study was that there would be no differences between the sealing ability of the materials.

\section{MATERIALS AND METHODS}

Seventy single-rooted human premolar teeth extracted for orthodontic reasons were selected for this study. The 
criteria for tooth selection were: straight single-rooted teeth with complete root formation; no root caries; no fracture line; a patent canal; root length of $11 \mathrm{~mm}$ to $13 \mathrm{~mm}$; and IAF size of \#15 or \#20. All specimens were donated by patients who were provided written and verbal informed consents to participate in this study. This study protocol was approved by the Institutional Review Board (IRB no. MD13022) of Korea University Medical Center. Root surfaces were scraped with a scalpel to remove periodontal ligament tissue and calculus. All teeth were stored in $0.5 \%$ chloramine- $\mathrm{T}$ solution for 1 week. The teeth were then stored in distilled water at $4^{\circ} \mathrm{C}$ (ISO/TS 11405/2003) until further processing. All procedures were performed by one endodontist.

The crowns of teeth were removed at the cementoenamel junction with a tapered fissure carbide bur (Mani, Tochigi-ken, Japan) in high-speed hand piece under water cooling. An apical stop was designated 1

Table 1 Materials used in this study

\begin{tabular}{|c|c|c|c|}
\hline $\begin{array}{c}\text { Product Name } \\
(\text { Lot \#) }\end{array}$ & Manufacturer & Composition & Application Technique \\
\hline $\begin{array}{l}\text { ProRoot WMTA } \\
(1100437 \text { 4E) }\end{array}$ & $\begin{array}{l}\text { Dentsply } \\
\text { Tulsa } \\
\text { Dental, } \\
\text { Tulsa, OK, } \\
\text { USA }\end{array}$ & $\begin{array}{l}\text { Powder: tricalcium } \\
\text { silicate, dicalcium } \\
\text { silicate, tricalcium } \\
\text { aluminate, } \\
\text { tetracalcium, } \\
\text { aluminoferrite, } \\
\text { bismuth oxide }\end{array}$ & $\begin{array}{l}\text { 1) Dispense the powder \& liquid(distilled water) onto a glass slab } \\
\text { (P/L=3/1) } \\
\text { 2) Mix the cement to ensure all the powder are hydrated } \\
\text { 3) Insert the mixed materials into a cavity using a carrier } \\
\text { 4) Remove excess cement }\end{array}$ \\
\hline $\begin{array}{l}\text { EndoCem Zr } \\
\text { (ZC2403120927) }\end{array}$ & $\begin{array}{l}\text { Maruchi, } \\
\text { Wonju, } \\
\text { Korea }\end{array}$ & $\begin{array}{l}\text { Powder: tricalcium } \\
\text { silicate, dicalcium } \\
\text { silicate, tricalcium } \\
\text { aluminate, } \\
\text { tetracalcium, } \\
\text { aluminoferrite, } \\
\text { bismuth oxide, } \\
\text { zirconium }\end{array}$ & $\begin{array}{l}\text { 1) Dispense the powder \& liquid(distilled water) onto a glass slab } \\
\text { (P/L=3/1) } \\
\text { 2) Mix the cement to ensure all the powder are hydrated } \\
\text { 3) Insert the mixed materials into a cavity using a carrier } \\
\text { 4) Remove excess cement }\end{array}$ \\
\hline $\begin{array}{l}\text { Angelus White } \\
(10349450023)\end{array}$ & $\begin{array}{l}\text { Angelus, } \\
\text { Londrina, } \\
\text { PR, Brazil }\end{array}$ & $\begin{array}{l}\text { Powder: tricalcium } \\
\text { silicate, dicalcium } \\
\text { silicate, tricalcium } \\
\text { aluminate, } \\
\text { tetracalcium, } \\
\text { aluminoferrite, } \\
\text { bismuth oxide }\end{array}$ & $\begin{array}{l}\text { 1) Dispense the powder \& liquid(distilled water) onto a glass slab } \\
\text { (P/L=3/1) } \\
\text { 2) Mix the materials to ensure all the powder are hydrated } \\
\text { 3) Insert the mixed materials into a cavity using a carrier } \\
\text { 4) Remove excess cement }\end{array}$ \\
\hline $\begin{array}{l}\text { LuxaCore } \\
(716491)\end{array}$ & $\begin{array}{l}\text { DMG, } \\
\text { Hamburg, } \\
\text { Germany }\end{array}$ & $\begin{array}{c}\text { Barium glass, pyrog. } \\
\text { silica in a Bis-GMA } \\
\text { based matrix of } \\
\text { dental resins }\end{array}$ & $\begin{array}{l}\text { 1) Etching the entire cavity for } 20 \mathrm{~s} \text { using } 37 \% \text { phosphoric acid. } \\
\text { 2) Thoroughly water rinse and lightly air dry the cavity } \\
\text { 3) Apply 3M ESPE Adper Single Bond } 2 \text { adhesive } \\
\text { 4) Gentle air stream } \\
\text { 5) Light cure for } 10 \mathrm{~s} \\
\text { 6) Insert LuxaCore into the cavity using automix cartilage } \\
\text { 5) Remove excess cement } \\
\text { 6) Light cure for } 40 \mathrm{~s}\end{array}$ \\
\hline $\begin{array}{l}\text { Fuji II LC } \\
(1211081)\end{array}$ & $\begin{array}{l}\text { GC, } \\
\text { Tokyo, } \\
\text { Japan }\end{array}$ & $\begin{array}{l}\text { Powder: FASG } \\
\text { Liquid: distilled } \\
\text { water, polyacrylic } \\
\text { acid, HEMA, UDMA, } \\
\text { camphorquinone }\end{array}$ & $\begin{array}{l}\text { 1) Cleaning the entire cavity using GC Dentin Conditioner for } 10 \mathrm{~s} \\
\text { 2) Thoroughly water rinse and lightly air dry the cavity } \\
\text { 3) Dispense powder and liquid onto mixing pad ( } \mathrm{P} / \mathrm{L}=3 / 1) \\
\text { 4) Gradually mix the liquid into the cement } \\
\text { 5) Insert the mixed material into a cavity using a Centrix syringe } \\
\text { 6) Remove excess cement } \\
\text { 7) Light cure for } 20 \mathrm{~s}\end{array}$ \\
\hline $\begin{array}{l}\text { Elite } \\
(1308011)\end{array}$ & $\begin{array}{l}\text { GC, } \\
\text { Tokyo, } \\
\text { Japan }\end{array}$ & $\begin{array}{l}\text { Powder: zinc oxide, } \\
\text { magnesium oxide } \\
\text { Liquid: distilled water, } \\
\text { phosphoric acid, } \\
\text { aluminum }\end{array}$ & $\begin{array}{l}\text { 1) Dispense the powder \& liquid onto a glass slab } \\
\text { 2) Gradually mix the liquid into the cement } \\
\text { 3) Insert the mixed Elite into a cavity } \\
\text { 4) Remove excess cement }\end{array}$ \\
\hline
\end{tabular}

MTA : Mineral trioxide aggregate, FASG : fluoro-aluminosilicate glass, HEMA : 2-hydroxyethylmethacrylate, UDMA : urethanedimethacrylate, $\mathrm{P} / \mathrm{L}$ : Powder to liquid ratio 
mm short of the point at which \#15 K-file (Mani) exited the apical foramen. Canals were then mechanically prepared in a crown down technique with a series of ProFile (Dentsply Maillefer, Tulsa, OK, USA). The apical foramen of each tooth was enlarged and kept patent to accommodate a 0.04 taper \#50 ProFile (Dentsply Maillefer). In an effort to eliminate debris, $5.25 \% \mathrm{NaOCl}$ was used as an irrigation solution between each file size. Using a \#5 Gates Glidden bur (Dentsply Maillefer), a uniform orifice cavity with a diameter of $1.3 \mathrm{~mm}$ and a depth of $4 \mathrm{~mm}$ was made. Solution of $17 \%$ EDTA (Pulpdent EDTA Solution 17\%; Pulpdent Co., Watertown, MA, USA) was used as a final rinse to remove smear layer. After drying the root canal with paper point, all root canals were filled by lateral condensation technique with 0.04 gutta-percha cones (Diadent Mfg Inc, Burnaby BC, Canada) and AH Plus sealer (Dentsply Maillefer). Coronal cavity was made by removing gutta-percha with the System B (SybronEndo, Orange, CA, USA) to the experimental depth of $3 \mathrm{~mm}$. The depth was verified with a North Carolina periodontal probe (Hu-Friedy, Chicago, IL, USA).

All of the 60 teeth were randomly divided into 6 groups, with the remaining ten teeth being divided equally into positive and negative controls. Six tested materials: white ProRoot MTA (ProRoot WMTA; Dentsply Maillefer), EndoCem Zr (Maruchi, Wonju, Korea), Angelus White (Angelus, Londrina, PR, Brazil), composite resin (LuxaCore; DMG, Hamburg, Germany), RMGI (Fuji II LC; GC, Tokyo, Japan), and ZPC (Elite; GC) were prepared according to the manufacturers' instructions and placed into the coronal orifice of each specimens of experimental groups (Table 1). In the LuxaCore group, etch-and-rinse bonding agent (Adper Single Bond2, 3M ESPE, St. Paul, MN, USA) was used. In the RMGI group, cavities were pretreated with $10 \%$ polyacrylic acid (Dentin Conditioner, GC) for $10 \mathrm{~s}$. For positive controls, five teeth were prepared without filling the root-orifice cavity. For negative controls, all the surfaces of five other teeth were coated using nail varnish (Revlon, Inc., New York, NY, USA). All specimens were incubated at $37^{\circ} \mathrm{C}$ with $100 \%$ humidity

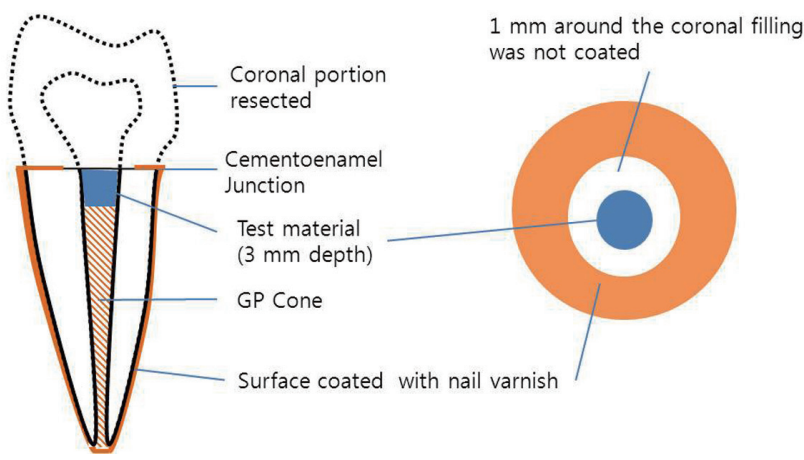

Fig. 1 Diagrammatic illustration showing the preparation of the experimental tooth. Left: Sagittal sectional view. Right: Cross sectional view. for 7 days. 5,000 cycles of thermocycling was performed between $5^{\circ} \mathrm{C}$ and $55^{\circ} \mathrm{C}$ with a dwelling time of $30 \mathrm{~s}$ as recommended by the International Organization for Standardization ${ }^{26)}$. After thermocycling, the surface of specimens was dried and coated twice using nail varnish except $1 \mathrm{~mm}$ around the coronal filling cavity side (Fig. 1). After $2 \mathrm{~h}$ drying the nail varnish, the specimens were immersed in $1 \%$ methylene blue for 10 days. The specimens were then washed under tap water for $1 \mathrm{~h}$ and air-dried. Mid-sagittal cutting was performed using a diamond disc (NTI-Kahla, Kahla, Germany) without water cooling to prevent dye removal.

To measure the length of dye penetration, digital images of specimen's cross-sections were taken with a digital camera (Nikon D3000, Japan). The maximum lengths of penetrations which occurred between the filling materials and the dentinal walls were measured in the longitudinal linear direction by image processing program ImageJ (NIH, Bethesda, MD, USA). ImageJ is a public domain, Java-based image processing program developed at the National Institutes of Health ${ }^{27,28)}$. It was designed with an open architecture that provides extensibility via Java plugins and recordable macros. Statistical analysis was performed by using SPSS software (IBM, Armonk, NY, USA). One-way ANOVA was used to compare differences in mean dye penetration length of the groups. Tukey's test was used for Post-hoc test. Significance was established at $p<0.05$.

\section{RESULTS}

After placing specimens into methylene blue dye, penetration occurred in a linear pattern between the



Fig. 2 Sagittal sectional views of tested groups. A: ProRoot WMTA. B: EndoCem Zr. C: Angelus White. D: LuxaCore. E: Fuji II LC. F: Elite. 
Table 2 Dye infiltration percentages of tested groups

\begin{tabular}{|c|c|c|c|c|}
\hline Materials & $n$ & Leakage (S.D.)\% & $\operatorname{Min} \%$ & $\operatorname{Max} \%$ \\
\hline ProRoot WMTA & 10 & $8.39(2.09)$ & 6.35 & 13.15 \\
\hline EndoCem $\mathrm{Zr}$ & 10 & $35.26(7.68)$ & 26.15 & 49.96 \\
\hline Angelus White ${ }^{\mathrm{a}}$ & 10 & $23.30(9.94)$ & 11.10 & 46.17 \\
\hline LuxaCore $^{a}$ & 10 & $18.97(7.90)$ & 9.75 & 37.83 \\
\hline Fuji II LC & 10 & $52.43(13.68)$ & 33.82 & 72.29 \\
\hline Elite & 10 & $88.93(9.36)$ & 65.20 & 98.15 \\
\hline Negative Control & 5 & 0 & - & - \\
\hline Positive control & 5 & 100 & - & - \\
\hline
\end{tabular}

a : groups are not significantly different $(p<0.05)$

Multiple Comparison result of dye penetration rate: ProRoot WMTA $<$ LuxaCore, Angelus White $<$ EndoCem $\mathrm{Zr}<\mathrm{Fuji}$ II LC $<$ Elite $(p<0.05)$



Fig. 3 Boxplots showing differences of mean and standard deviations of dye infiltrations for tested materials.

filling materials and the dentinal walls (Fig. 2). The same pattern occurred regardless of the obstruction materials. The dye penetration values of the groups are summarized in Table 2 and Fig. 3. Comparing the penetration depth of each materials using SPSS, unlike null hypothesis, the statistical analysis showed significant differences among all tested materials except between LuxaCore and Angelus White. ProRoot WMTA showed the less penetration value among all other materials, LuxaCore, Angelus White, EndoCem Zr, Fuji II LC, and Elite followed respectively the ProRoot WMTA $(p<0.05)$.

\section{DISCUSSION}

Preventing leakage is essential to maintain a successful sealing of the root canal system. In addition, coronal restoration is an important requisite for long-term endodontic success ${ }^{1}$. Coronal sealing materials should provide a stable and leak-proof sealing ability. The defect of a temporary or a permanent restoration during or after root canal treatment is the main cause of coronal leakage ${ }^{29)}$. For this reason, the coronal part of the root canal should be sealed as tightly as possible. If the coronal seal materials were weak or unsuitable, the use of the materials as a coronal orifice barrier could mitigate bacterial filtration ${ }^{30)}$.

A variety of in vitro experimental methods were used to evaluate microleakage through filled roots such as dye penetration, bacterial leakage, electrochemical method, fluid filtration, radioisotope labelling, and scanning electron microscope analysis ${ }^{31)}$. In this study, methylene blue dye penetration was used. Dye penetration experiment using various types of dyes (eosin, methylene blue, black India ink, Procion brilliant blue, and others) is widely used ${ }^{32,33)}$ because it is inexpensive, easy to manipulate, and it has a high degree of staining property. Also it has molecular weight even lower than that of bacterial toxins, so it has similar leakage to butyric acid, which is a microbial metabolic product ${ }^{34)}$. Despite these advantages, there are several disadvantages to use the dye penetration methods, including dissolution during the demineralization process and the difficulty to observe maximum infiltration point in some cases ${ }^{35)}$.

Timpawat et al. ${ }^{36)}$ reported that the use of bacteria to assess coronal leakage is considered to be of clinical and biological relevance. However, those bacterial studies have been qualitative rather than quantitative. If only one bacterium passes through the obturated root canal, it may multiply in the enriched broth and cause turbidity ${ }^{37,38)}$. The use of bacteria to assess coronal leakage also has its limitation because some of sealing materials have antibacterial activities ${ }^{39)}$.

Various materials have been tested for their ability to prevent microleakage as a coronal seal or as a temporary 
restoration. Jenkins et al. reported that Tetric, the lightcured resin, leaked less than Cavit or ProRoot MTA, with using Indian $i n k^{30)}$. Pisano et al. tested the coronal sealing ability of temporary filling materials to prevent microleakage of gutta-percha obturated root canals in human saliva and revealed that the IRM, Cavit, SuperEBA-filled orifice leaked less leakage than unsealed control group ${ }^{40)}$. Another microleakage study ${ }^{41)}$ using glucose penetration model showed that Cavit, Tetric, and ProRoot MTA attained similar leakage values during the testing period when used as intraorifice barriers. As described above, previous researches support the importance of intraorifice barriers, but there is no consensus as to the protocols or materials used as the coronal barrier after root canal treatment except the thickness of the intraorifice barrier, which is recommended to be 3 to $4 \mathrm{~mm}^{40,42,43)}$. As all studies differ in methodologic designs and materials, this difference makes difficult to compare material's ability on preventing microleakage.

This study was designed to compare the coronal sealing ability of MTA-derived materials (ProRoot WMTA, EndoCem Zr, and Angelus White) and several established restorative materials (LuxaCore, Fuji II LC, and Elite). Our results revealed that ProRoot WMTA had the best sealing ability against dye (Table 2). It has been reported that MTA-based materials have the hydrophilic feature and the slight expansion tendency ${ }^{44)}$, which can attribute to the superior sealability of MTA in this study.

On the contrary, EndoCem $\mathrm{Zr}$ showed significantly less sealability compared to other two MTA-based materials (ProRoot WMTA and Angelus White) used in this study, although it is a MTA-derived material. EndoCem is a recently introduced MTAderived pozzolan cement which contains small particle pozzolan cement that has fast setting property ${ }^{45)}$. EndoCem Zr, recommended for use in anteriors, is a color and additive modified type of EndoCem. According to the manufacturer, bismuth oxide in EndoCem as a radiopacifier was replaced by zirconia powder. For this reason, EndoCem Zr has whitish color and the amount of calcium hydroxide generated during the setting process is smaller than that of EndoCem, which may affect its sealability. The bismuth was known to affect the precipitation of calcium hydroxide in the hydrated paste ${ }^{22)}$.

The microleakage values of LuxaCore were found to be non-significantly different with Angelus White. This potent sealing ability was probably due to the use of dentin bonding agent. Nevertheless, the polymerization contraction maybe contributed the results of this microleakage test.

In case of Fuji II LC, the microleakage values showed greater deviation than other materials used in this study (Fig. 3). The conceivable causes are followed. Fuji II LC consists of two bottles, powder and liquid, but the powder particles are not consistant and the hand-mixing procedure is hard to make a uniform mass without internal void. In this study, Fuji II LC leaked greater than other materials except Elite. It has reported that different experimental conditions may contribute to the results of the study ${ }^{46-49)}$. In their studies, the authors have concluded that the polymerization shrinkage of RMGIs can be reduced by water uptake. While in endodontically treated teeth, the possibility of water absorption could be restricted, self-desiccation may lead to eventual shrinkage of RMGIs, which is resulting in greater leakage in this study. If the Fuji II LC automix capsule is included in the future experimental group, it can be seen that how much the hand-mixing procedure contributes to the deviation of the microleakage values. About bonded resins and RMGIs, there have been reported that they have successful properties to prevent coronal microleakage in other studies ${ }^{2,50)}$. Tselnik et al. reported that gray MTA, white MTA, and Fuji II LC provided a coronal sealing ability for up to 90 days with no significant differences in performance as coronal barrier materials ${ }^{50)}$. More research studies are needed to determine exactly which material will perform the best as coronal barrier material.

Wilcox et al. ${ }^{51)}$ revealed that all groups with ZPC as a base after the root canal filling with gutta-percha and sealer using lateral condensation technique, had specimens which leaked into the gutta-percha. The result presented in this study is in agreement with that of our study that all the Elite groups leaked to the guttapercha. Another study showed that bonding strength of $\mathrm{ZPC}$ was low values in a range of 4.6 to $23.5 \mathrm{kgf} / \mathrm{cm}^{2}$, which is lower value than polycarboxylate cement and glass-ionomer cement ${ }^{52)}$. In spite of several advantages of $\mathrm{ZPC}$, which are the longest clinical data, convenience of usage, and inexpensiveness, it is brittle, lack of adhesion and soluble in the mouth. Also increasing amount of water results in the reduction of both the compressive and tensile strength ${ }^{53)}$. As for the previous researches and the results of this study, the use of Elite as an intraorifice barrier is no recommended.

All the teeth in positive control group, which received no intraorifice barrier in the orifice of root cavity, leaked methylene blue to the apex. On the other hand, negative control roots which were used to ensure the microleakage of dye had no penetration in this study.

When considering the core placement after root canal treatment, the bonding between MTA-derived materials as an intraorifice barrier and core resin is also important. Conflicting results have been reported regarding the contribution of various adhesive systems to the bond strength between MTA-derived materials and composite ${ }^{54,55)}$. Shin et al. ${ }^{54)}$ revealed that AdheSE OneF (one-step self-etching system) showed the highest shear bond strength, while Bayrak et al. ${ }^{55)}$ reported that etch-and-rinse adhesive systems exhibited higher bond strength than self-etch adhesive systems. In this study, the ProRoot WMTA showed the lowest microleakage value, followed by LuxaCore and Angelus White (Table 2). Based on our research findings, coronal leakage might be reduced if ProRoot WMTA is placed as an intraorifice barrier before the resin core filling to root canal treated tooth. The results of this study suggests that MTA- 
based sealing materials might be used not only as apical barriers but also as coronal barriers. However, further studies should be conducted to evaluate MTA's sealability in comparison with other commercially available coronal sealing materials using various methods.

\section{CONCLUSION}

Despite the limitations of this study, the authors found all coronal filling materials which were used as an intraorifice barrier allowed infiltration of dye. The order of less dye penetration was: ProRoot WMTA<LuxaCore, Angelus White $<$ EndoCem $\mathrm{Zr}<$ Fuji II LC $<$ Elite. Two MTA-based materials (ProRoot WMTA, Angelus White) and LuxaCore showed significantly smaller penetration and less variation than other materials (EndoCem $\mathrm{Zr}$, Fuji II LC and Elite).

\section{REFERENCES}

1) Saunders WP, Saunders EM. Coronal leakage as a cause of failure in root canal therapy: a review. Endod Dent Traumatol 1994; 10: 105-108.

2) Wolanek GA, Loushine RJ, Weller RN, Kimbrough WF, Volkmann KR. In vitro bacterial penetration of endodontically treated teeth coronally sealed with a dentin-bonding agent. J Endod 2001; 27: 354-357.

3) Roghanizad N, Jones JJ. Evaluation of coronal microleakage after endodontic treatment. J Endod 1996; 22: 471-473.

4) Beckham BM, Anderson RW, Morris CF. An evaluation of three materials as barriers to coronal microleakage in endodontically treated teeth. J Endod 1993; 19: 388-391.

5) Barthel CR, Zimmer S, Wussogk R, Roulet JF. Long-term bacterial leakage along obturated roots restored with temporary and adhesive fillings. J Endod 2001; 27: 559-562.

6) Wells JD, Pashley DH, Loushine RJ, Weller RN, Kimbrough WF, Pereira PN. Intracoronal sealing ability of two dental cements. J Endod 2002; 28: 443-447.

7) Mah T, Yared G, Friedman S. Periapical inflammation affecting coronally inoculated dog teeth with root fillings augmented by white MTA orifice plugs. J Endod 2003; 29: 442-446.

8) Mavec JC, Minah GE, Blundell RE, McClanahan SB, Johnson JD. Effects of an intracanal glass ionomer barrier on coronal microleakage in teeth with post space. J Endod 2006; 32: 120122.

9) Torabinejad M, Hong CU, Pitt Ford TR, Kariyawasam SP. Tissue reaction to implanted SuperEBA and mineral trioxide aggregate in the mandible of guinea pigs: a preliminary report. J Endod 1995; 21: 569-571.

10) Torabinejad M, Pitt Ford TR, Abedi HR, Tang HM. Tissue reaction to implanted root-end filling materials in the tibia and mandible of guinea pigs. J Endod 1998; 24: 468-471.

11) Torabinejad M, Hong CU, Lee SJ, Monsef M, Pitt Ford TR. Investigation of mineral trioxide aggregate for root-end filling in dogs. J Endod 1995; 21: 603-608.

12) Torabinejad M, Pitt Ford TR, McKendry DJ, Abedi HR, Miller DA, Kariyawasam SP. Histologic assessment of mineral trioxide aggregate as a root-end filling in monkeys. J Endod 1997; 23: 225-228.

13) Pitt Ford TR, Torabinejad M, Abedi HR, Bakland LK, Kariyawasam SP. Using mineral trioxide aggregate as a pulpcapping material. J Am Dent Assoc 1996; 127: 1491-1494.

14) Aeinehchi M, Eslami B, Ghanbariha M, Saffar AS. Mineral trioxide aggregate (MTA) and calcium hydroxide as pulp- capping agents in human teeth: a preliminary report. Int Endod J 2003; 36: 225-231.

15) Faraco IM Jr, Holland R. Response of the pulp of dogs to capping with mineral trioxide aggregate or a calcium hydroxide cement. Dent Traumatol 2001; 17: 163-166.

16) Pitt Ford TR, Torabinejad M, McKendry DJ, Hong CU, Kariyawasam SP. Use of mineral trioxide aggregate for repair of furcal perforations. Oral Surg Oral Med Oral Pathol Oral Radiol Endod 1995; 79: 756-763.

17) Arens DE, Torabinejad M. Repair of furcal perforations with mineral trioxide aggregate: two case reports. Oral Surg Oral Med Oral Pathol Oral Radiol Endod 1996; 82: 84-88.

18) Shabahang S, Torabinejad M, Boyne PP, Abedi H, McMillan $\mathrm{P}$. A comparative study of root-end induction using osteogenic protein-1, calcium hydroxide, and mineral trioxide aggregate in dogs. J Endod 1999; 25: 1-5.

19) Abedi HR, Ingle JI. Mineral trioxide aggregate: a review of a new cement. J Calif Dent Assoc 1995; 23: 36-39.

20) Schwartz RS, Mauger M, Clement DJ, Walker WA 3rd. Mineral trioxide aggregate: a new material for endodontics. J Am Dent Assoc 1999; 130: 967-975.

21) Camilleri J, Montesin FE, Brady K, Sweeney R, Curtis RV, Ford TR. The constitution of mineral trioxide aggregate. Dent Mater 2005; 21: 297-303.

22) Camilleri J. Hydration mechanisms of mineral trioxide aggregate. Int Endod J 2007; 40: 462-470.

23) Sarkar NK, Caicedo R, Ritwik P, Moiseyeva R, Kawashima I. Physicochemical basis of the biologic properties of mineral trioxide aggregate. J Endod 2005; 31: 97-100.

24) Bozeman TB, Lemon RR, Eleazer PD. Elemental analysis of crystal precipitate from gray and white MTA. J Endod 2006; 32: 425-428.

25) Asgary S, Eghbal MJ, Parirokh M, Ghoddusi J. Effect of two storage solutions on surface topography of two root-end fillings. Aust Endod J 2009; 35: 147-152.

26) Dental materials - Testing of adhesion to tooth structure. Geneva, Switzerland: International Organization for Standardization; 2003. ISO/TS 11405.

27) Schneider CA, Rasband WS, Eliceiri KW. NIH Image to ImageJ: 25 years of image analysis. Nat Methods 2012; 9: 671-675.

28) Collins TJ. ImageJ for microscopy. BioTechniques 2007; 43(1 Suppl): 25-30.

29) Chong BS. Coronal leakage and treatment failure. J Endod 1995; 21: 159-160.

30) Jenkins S, Kulild J, Williams K, Lyons W, Lee C. Sealing ability of three materials in the orifice of root canal systems obturated with gutta-percha. J Endod 2006; 32: 225-227.

31) Alani AH, Toh CG. Detection of microleakage around dental restoration: a review. Oper Dent 1997; 22:173-185.

32) Camps J, Pashley D. Reliability of the dye penetration studies. J Endod 2003; 29: 592-594.

33) Kontakiotis EG, Georgopoulou MK, Morfis AS. Dye penetration in dry and water-filled gaps along root fillings. Int Endod J 2001; 34: 133-136.

34) Kersten HW, Moorer WR. Particles and molecules in endodontic leakage. Int Endod J 1989; 22: 118-124.

35) Ahlberg KMF, Assavanop P, Tay WM. A comparison of the apical dye penetration patterns shown by methylene blue and India ink in root filled teeth. Int Endod J 1995; 28: 30-34.

36) Timpawat S, Amornchat C, Trisuwan WR. Bacterial coronal leakage after obturation with three root canal sealers. J Endod 2001; 27: 36-39.

37) Britto LR, Grimaudo NJ, Vertucci FJ. Coronal microleakage assessed by polymicrobial markers. J Contemp Dent Pract 2003; 4: 1-10.

38) Chailertvanitkul P, Saunders WP, Saunders EM, MacKenzie D. An evaluation of microbial coronal leakage in the restored pulp chamber of root-canal treated multirooted teeth. Int 
Endod J 1997; 30: 318-322.

39) Torabinejad M, Hong C, Pitt Ford TR, Kettering J. Antibacterial effects of some root-end filling materials. J Endod 1995; 21: 403-406.

40) Pisano DM, DiFiore PM, McClanahan SB, Lautenschlager EP, Duncan JL. Intraorifice sealing of gutta-percha obturated root canals to prevent coronal microleakage. J Endod 1998; 24: 659-662.

41) Bailon-Sanchez ME, Gonzalez-Castillo S, Gonzalez-Rodriguez MP, Poyatos-Martinez R. Intraorifice sealing ability of different materials in endodontically treated teeth. Med Oral Patol Oral Cir Bucal 2011; 16: 105-109.

42) Sauáia TS, Gomes BP, Pinheiro ET, Zaia AA, Ferraz CC, Souza-Filho FJ. Microleakage evaluation of intraorifice sealing materials in endodontically treated teeth. Oral Surg Oral Med Oral Pathol Oral Radiol Endod 2006; 102: 242246.

43) Wolcott JF, Hicks ML, Himel VT. Evaluation of pigmented intraorifice barriers in endodontically treated teeth. J Endod 1999; 25: 589-592.

44) Torabinejad M, Watson TF, Pitt Ford TR. Sealing ability of a mineral trioxide aggregate when used as a root end filling material. J Endod 1993; 19: 591-595.

45) Choi Y, Park SJ, Lee SH, Hwang YC, Yu MK, Min KS. Biological effects and washout resistance of a newly developed fast-setting pozzolan cement. J Endod 2013; 39: 467-472.

46) Brackett W, Gunnin T, Johnson W, Elaine Conkin J. Microleakage of light cured glass ionomer restorative materials. Quintessence Int 1995; 26: 583-585.

47) Brackett W, Gunnin T, Russell O. Microleakage of class V compomer and light cured glass ionomer restoration. J Prosthet Dent 1998; 79: 261-263.

48) Croll TP, Segura A, Donly K. Clinical performance of resin modified glass ionomer cement restorations in primary teeth: A retrospective evaluation. J Am Dent Assoc 2001; 132: 11101116.

49) Gerdolle DA, Mortier E, Droz D. Microleakage and polymerization shrinkage of various polymer restorative materials. J Dent Child 2008; 5: 125-132.

50) Tselnik M, Baumgartner JC, Marshall JG. Bacterial leakage with mineral trioxide aggregate or a resin-modified glass ionomer used as a coronal barrier. J Endod 2004; 30: 782 784.

51) Wilcox LR, Diaz-Arnold A. Coronal microleakage of permanent lingual access restorations in endodontically treated anterior teeth. J Endod 1989; 15: 584-587.

52) Suga T, Chiba E, Shinya A, Yokozuka S. Studies on bond strength and hardness of base materials. Shigaku 1989; 76: 1394-1411.

53) Anusavice KJ. In: Anusavice KJ, editor. Phillips' science of dental materials. 12th ed. St. Louis: Saunders Co; 2003. p. 307-339.

54) Shin JH, Jang JH, Park SH, Kim ES. Effect of mineral trioxide aggregate surface treatments on morphology and bond strength to composite resin. J Endod 2014; 40: 12101216.

55) Bayrak S, Tunç ES, Saroğlu I, Eğilmez T. Shear bond strengths of different adhesive systems to white mineral trioxide aggregate. Dent Mater J 2009; 28: 62-67. 